\title{
Vaginal Cancer Pathologic Distant Metastasis TNM Finding v8
}

National Cancer Institute

\section{Source}

National Cancer Institute. Vaginal Cancer Pathologic Distant Metastasis TNM Finding v8. NCI Thesaurus. Code C139638.

A pathologic finding about one or more characteristics of vaginal cancer, following the rules of the TNM AJCC V8 classification system as they pertain to distant metastases. 